\title{
A BRIEF HISTORY OF FACTIONALISM AND NEW PARTY FORMATION AND DECLINE IN SOUTH AFRICA The Case of Cope
}

\author{
Ivor Sarakinsky and Ebrahim Fakir \\ Ivor Sarakinsky is Senior Lecturer, Graduate School of Public and Development \\ Management, University of the Witwatersrand. \\ email: Ivor.Sarakinsky@wits.ac.za \\ Ebrahim Fakir is Manager, Political Parties and Parliamentary Programme; EISA \\ email: ebrahim@eisa.org.za
}

\begin{abstract}
There is little analytical literature on the theory and empirical analysis of party factionalism that leads to splits and the formation of new political entities. The existing theoretical literature identifies factors and processes that are split-enabling. When coupled to the dynamics of organisational change, these conceptual tools provide a unique framework for analysing party-political dynamics in South Africa from an historically comparative perspective. This analysis identifies key trends in party splits in both 'white' and 'black' politics, which serves to illuminate more recent developments with regard to the realignment of opposition politics in South Africa. A conceptual framework combining organisational theory with the literature on party factionalism and party splits has facilitated our case-study focus on the formation, electoral performance and decline of the Congress of the People (Cope) as an opposition party in South Africa. We argue that Cope emerged from factional disputes within the ANC and has subsequently largely been shaped by the dynamics of its split and formation from the ANC, despite its attempt to break ties with the parent party. Existing analyses of Cope examine its performance in terms of policy, electoral and oppositional performance, while the approach this article adopts is to argue that the process of Cope's formation significantly shaped the conditions of its future internal dynamics and political performance.
\end{abstract}




\section{INTRODUCTION}

The emergence of the Congress of the People (Cope) from the bitter conflict marking the ANC's 2007 Polokwane Conference requires careful analysis. While Jacob Zuma triumphed over Thabo Mbeki and his allies, the formation of a new political party out of that milieu appears, at one level, to be unique. The intensity of the leadership dispute, the high-level status of the main players with the prosecutorial agencies investigating Zuma, suggest that this was all a contingent moment in South Africa's recent democratic history.

In all political parties, decisions are made in terms of constitutions and rules and there are winners and losers. Competition over positions and contests over policy occur in all parties. Usually they are mediated and contained through the systematic processes defined by the parties' rules and procedures. Losers have two options: resign should they deem the position and policy outcomes unacceptable, or accept the decision, seek to tweak it, and work to build a constituency within the party cadre-ship and supporters; or change things at the next available platform or opportunity as defined in the decision-making processes and structures of the party or at the next conference.

Intense wrangling and high-stakes gambits are a feature of all political party leadership contests around the world. Where these have sufficient outlets and platforms for the airing and expression of difference and are conducted and systematised through appropriate and adequate processes of inclusive decisionmaking, distribution of positions and resources within the party across factions and cleavages and appropriate conflict management, mitigation and containment processes, parties are able to maintain a degree of cohesion and unity. In the absence of platforms for expressing difference, or distribution of positions, or bargained outcomes on policy and when the differences among members and leaders are too great, there is an extensive and prolonged sense of grievance. This sometimes finds expression in behaviour outside the rules of the commonly agreed game (party constitutions and processes). When the stakes for position, either leadership or policy, are so high that leaders and members conspire to give them effect and make them binding, without following the agreed upon rules, new issues of conflict are introduced and layered on to existing ones. This tests and undermines the very set of rules that binds the members and leaders together in an organisation and manifests in splits, splinters and breakaways, often leading to new political formations.

There is nothing unusual about this in the comparative study of political party formation. What is important in this process, for an analysis of Cope, is the difference between a party forming to represent neglected constituencies or to address ignored issues and challenges in society and one that is a splinter from 
an existing party, in this case, the African National Congress (ANC). This has salience for locating an understanding of Cope within its own genesis, as well as for the processes of splits and the subsequent decline within the party.

Parties formed to represent neglected constituencies or to address ignored issues and challenges in society engage in a positive type of political entrepreneurship and identify and build a constituency as their power base in society in order to address identified social challenges. The Workers Party in Brazil or Green parties in Western Europe are good examples of this. A break from the parent party leads to a very different type of politics, with precarious prospects for success. As a splinter, the new party cannot escape its association with the parent party and the nature of the ensuing political and identity contests, as well as leadership struggles and policy disputes, shape the nature and character of the new entity.

While emerging from a parent party, the new entity tries to differentiate itself from that party in order to attract votes. This type of political entrepreneurship usually entails claiming to represent the true values and vision of what the new party refers to as the now misguided original parent party. An example of this is the 1981 formation of the Social Democratic Party out of a split from the Labour Party in the United Kingdom. Parties that come into being premised on a split from the parent tend to experience initial success. However, over time, they either evaporate or join up with other smaller parties to form new entities that remain on the margins of a democratic political party system. Perhaps one exception is the Liberal Democrats in the United Kingdom, a merger of the Social Democratic Party and the Liberal Party in 1988.

While most splinter parties emerge from parties in opposition, the case of Cope is interesting as it arose from a breakaway from the ANC, the party in power. The study of Cope, including its emergence and performance in elections, is an important contribution to the literature on party splinters. Our approach has been to adopt a macro perspective on Cope's formation and subsequent electoral performance. The first section of this analysis engages with the body of theoretical literature dealing with splits, splinters and breakaways leading to new political parties and is aimed at illuminating the second section, which deals with the genesis of Cope. It is followed by an overview of party splits in South Africa since Union in 1910. This will provide some historical insight into the patterns of party formation in South Africa. The next section will examine the context and reasons for Cope breaking away from the ANC. It will attempt to establish whether personality clashes, contests for leadership, a new ideology and politics caused the split and whether the importation of these issues shaped the new party. The fourth section analyses Cope's electoral performance in the 2009 national, 2011 municipal and 2014 national elections. This data will enable 
an assessment of Cope's longer-term sustainability and contribution to the South African body politic.

\section{CONCEPTUAL FRAMEWORK: PARTIES, FACTIONS AND SPLITS}

The first comprehensive analysis of internal party dynamics is presented by Sartori. He develops a framework for the analysis of factions in parties in a chapter entitled 'The Party from Within'. Here it is asserted that there is no such thing as a uniform party and that factions, tendencies and groupings are a feature of all political parties. Sartori (2005, pp 65, 66, 93) goes as far as declaring that 'the nature of a party is in the nature of its factions $(2005: 65,66,93)$. After defining 'faction', Sartori identifies four factors that, individually or in combination, cause factions to come into being. At the same time, factions in a party are not static and their character changes over time in response to the identified determining variables. Sartori (2005, pp 67-70) lists these variables as: organisational, motivational, ideological and left-and-right. Factions take an organised form; there are reasons, interests and principles that lead to their formation; they are based on ideas as well as ideals and they are also informed by positioning in relation to influential policy positions of the party. All of this is dynamic and Sartori (2005, p 68) is at pains to stress that one factor might act as camouflage for another, making it difficult to untangle the 'real' determining variables when analysing intra-party dynamics. While the earlier writers on parties emphasised fusion, Sartori focuses in his categorisation of parties on managed fission, thereby illuminating their dynamic and complex nature.

Sartori (2005, pp 82-7) then situates these dynamics within a broader context of what he calls 'the structure of opportunities'. In particular, he examines the 'intra-party electoral system' or the rules that regulate how politicians in a party compete for leadership positions and office. Sartori $(2005, \mathrm{p}$ 86) emphasises the importance of these rules, declaring: 'There is no exaggeration, therefore, in asserting that the intra-party electoral arrangements are, for the career-seeking politician, his routes to incumbency, or his pathways to success.' In other words, factions can estimate their respective strengths in terms of the decision rules, while distorting such rules to their advantage in electoral contests (Benton 2007, p 61). This is the 'invisible' dimension of deep internal party politics and the 'visible' dimension of such politics is only slightly exposed through 'inter-party electoral competition'. Factional and alliance politics is like an iceberg, the bulk occurs out of public sight, with only the tip, the outcome of a contest, being visible. These insights into factions and the rules for holding internal electoral contests provide a powerful understanding of the way in which parties function and, as will be argued below, why they sometimes split. 
More recent literature on intra-party factionalism examines in a more complex manner the impact of this phenomenon on political parties. There is a broad consensus that factions have positive consequences for parties (Boucek 2009, p 476, Carty 2004, p 14, Verge \& Gomez 2012, p 671). These positives include strengthening internal party processes, enabling the party to appeal to a broader constituency, contributing to better decision-making, integrating diversity into manifestos, moderating party leaders' responses to issues and facilitating coordination within parties. In clarifying the effects of factionalism, Boucek (2009, pp 469-78) distinguishes among three different types of factionalism: cooperative - consensus-building dynamics; competitive - polarisation caused by disagreements and different preferences and degenerative - perverse incentives and mismanagement leading to actions that may destroy the party or lead to splits. Again, the variables are contingently inter-related and a dispute over policy could be a proxy for, or lead to, a leadership contest (Carty 2004, p 20). For Boucek, the first two types of factions are positive and only the latter has, obvious negative consequences for the party itself. However, it is one thing to describe factional dynamics within parties and another to explain why parties either disintegrate or split due to factionalism. This framework on factionalism is important for an analysis of party splits as it serves as a foundation for developing a theory of party splintering, an area of political analysis that has not received much attention (Asal, Brown \& Dalton 2012, p 95; Dyck \& Starke 1999, p 792). While factionalism may be considered a split-enabling condition, more work is needed to provide a theory of why splits occur. The basis of such theorising is found in the discipline of organisation theory and Hirschman's exit/voice/loyalty/neglect (EVLN) paradigm.

According to this model there are four behaviours in organisations: exit is the severing of ties with the parent organisation, voice denotes proposing changes to improve the organisation, loyalty means waiting for others to address a problem in the organisation and neglect refers to lowering the level of participation in the organisation (Dyck \& Starke 1999, p 794). One of the criticisms of this approach is that it does not examine the process where one behaviour changes into another, with exit being the focus of analysis. Various writers develop stage and process flow models of this with the identification of relevant causal factors associated with such behaviour change. Dyck \& Starke (1999, p 806) propose a six-stage model, while other writers present a five-stage model explaining why organisations split (See Figure 1).

Dyck \& Starke (1999, p 811) also identify conditions and interventions that might reduce conflict, and thereby prevent the breakaway, with transparency in the development of new ideas, mediation and external unifying events being important. However, literature cited by Dyck \& Starke (1999, p 793) identifies 


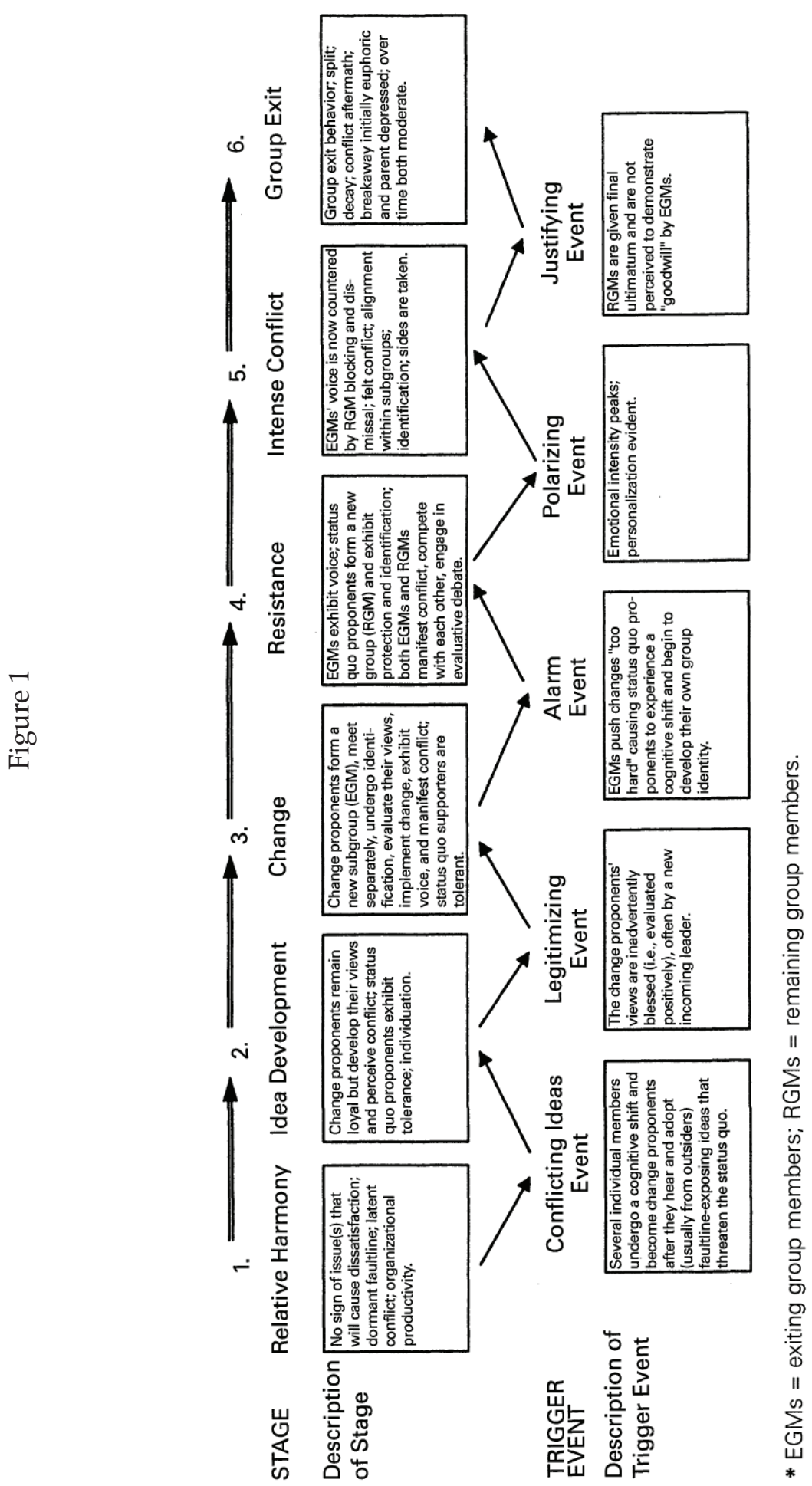


four features of the breakaway organisation that forms after the group exit stage: It is formed by a group rather than an individual, the founding group members have experience working together, the founding group comes from a similar parent and the ideas of the new group are based on ideas emanating from the parent organisation. There is more recent literature on the formation of new political parties in this context, with attempts to define more precisely what is meant by 'new' (Zons 2013, Barnea \& Rahat 2010). While these studies are overly descriptive, they also give arbitrary criteria for the classification of new political parties. Therefore, the four factors identified above are more useful in examining the nature of political parties formed out of a breakaway from a parent party.

What this theoretical discussion of political party factionalism shows is that unless properly managed, factionalism has negative consequences for the organisation and can lead to dysfunction and breakaways. In this regard, leadership and unexpected events are key variables in intensifying or managing factional behaviour in organisations. The former is much easier to identify, analyse and predict. The latter is the dreaded 'unknown unknown', or contingent event, that places organisations at the mercy of what Machiavelli (1985, p 130) called 'fortune', 'the arbiter of half the things we do, leaving the other half or so to be controlled by ourselves'. Such events expose organisational faultlines and leadership either builds consensus or its absence contributes to splits and breakaways.

This is relevant to a study of Cope as, during the interregnum in 2007 at Polokwane, the proposal to extend the term of office of the ANC president, not the Republic of South Africa president, blew open the factionalism that had been bubbling under in the ANC for some time. The birth of Cope lies in this context, as does its decline, susceptible as it was to its own factionalism, expressed through its leadership, identity, institutional, and organisational cleavages - many of which were imported into it from the political culture of the ANC, the party movement from which it had split.

\section{BRIEF OVERVIEW OF POLITICAL SPLITS IN SOUTH AFRICA, 1910-2002}

An examination of party splits in South Africa provides some insight into the dynamics of such breakaways and also shows some important trends that are relevant to an analysis of Cope. In particular, a breakaway party has to receive significant support and hold a meaningful number of seats in Parliament if it is to survive. An examination of the dynamics in the National Party (NP) demonstrates why it serves as a counter-example to the literature on party splits that suggests that resulting parties '... most commonly ... often disappear' (Asal, Brown \& Dalton 2012, p 98). 
After Union, and under an essentially white franchise, the South African Party (SAP) emerged as the majority party in the first Parliament. Shortly thereafter, the tensions of former enemies in the Anglo Boer War being in the same government came to the fore. In January 1914, the National Party, led by General J B M Hertzog, was formed in Bloemfontein. It articulated a position of South African autonomy and equal language rights for English and Afrikaans. It also stood against South Africa siding with England and participating in World War 1 (Davenport 1984, p 175). Over the next 20 years, the NP increasingly grew its support at successive elections and, by 1933, had tripled its initial support among the electorate.

In 1933 Hertzog took the NP into the fusion government, an alliance of the SAP, the NP and other parties. This progress stumbled in 1935, when D F Malan led a breakaway from the NP and formed the Gesuiwerde (purified) NP. This was in response to Hertzog agreeing to join a fusion government with the SAP and other parties in 1933, partly in response to an economic crisis. In the 1938 election the NP under Malan held 27 seats, the same number the newly formed NP under Hertzog had received in the 1915 election. In the 1943 election, Malan's NP had increased its seats to 43 and in the 1948 election it won the majority of seats with an overall minority national vote, thereby forming the government and ushering in the policy of apartheid.

Between 1948 and 1969 the NP was coherent through strong leadership and clear policy objectives, namely, the implementation of apartheid. However, in the late 1960s factionalism emerged, with a small grouping, led by Albert Hertzog, the son of General Hertzog, breaking away to form the Herstigte (reconstituted) Nasionale Party in 1969. This was in response to Maori members of the New Zealand rugby team being allowed to tour South Africa and to the National Party government under B J Vorster establishing diplomatic ties with other African countries. The motive behind the breakaway was to stand firm on racial separation and apartheid policy, in contrast to small pragmatic shifts being allowed by the former parent party in power.

In successive elections, the HNP established the ignominious record of never winning a single seat in Parliament. Similarly, in 1982, there was a more significant breakaway from the NP when the Conservative Party, led by Andries Treurnicht, was formed. This party was against any reform of racial policy and focused its opposition on the NP's implementation of the Tri-Cameral Constitution in 1983 that brought whites, Indians and coloureds into some form of consociational arrangement. The Conservative Party grew its support in successive elections, but was never able to challenge seriously for power.

White opposition to the NP in the post-1948 period also exhibited factional behaviour and splits, resulting in the formation of new political parties. In 1959, 
a grouping left the United Party (UP) and started the Progressive Party (PP). A small number of members of the Liberal Party, formed in 1953, left their parent and joined the Progressive Party shortly after its formation. This new party proposed a more liberal approach to the rights of blacks in South Africa, who did not have franchise rights under apartheid. In pursuing a liberal agenda, the PP had a small number of members in Parliament and for some time only one member, namely Helen Suzman. This liberal party underwent numerous changes as it amalgamated with others leaving the UP and successively changed its name to Progressive Reform Party and then to the Progressive Federal Party (PFP). The PFP lost its status as the official opposition after the 1987 election and was replaced by the $\mathrm{CP}$, discussed above. More recently, the PFP further changed its name and absorbed other parties, to become the Democratic Alliance (DA), currently the official opposition in South Africa.

Breakaways were not just a feature of 'white' politics in the pre-1994 era of racial discrimination and a racially-based franchise. The South African Native National Congress was formed in Bloemfontein in 1912, a year before the NP, to mobilise against the 1913 Land Act. The name of the organisation was changed in 1923 to the African National Congress and, despite differences and tensions within, was remarkably unified for a long time. This was due to its campaigning against discriminatory policy and an increasingly repressive environment, with the authorities acting every more oppressively against opposition movements. This was demonstrated in the mass-based Defiance campaigns in the 1950s, culminating in the drafting of the Freedom Charter in 1955 (see Lodge 1983 for details). The Freedom Charter marked the culmination of efforts by a range of organisations representing all racial groups in South Africa. This success in unifying opposition to apartheid across racial lines, ironically, initiated a process of factionalism that would lead to a split and the formation of a breakaway party, the Pan Africanist Congress (PAC), in 1959.

The PAC was born and pursued an Africanist opposition agenda, objecting to the role of whites and communists in the earlier Defiance campaigns. It succeeded in mobilising large numbers of people around destroying passes, identity documents that had to be carried by all blacks, proving that they were allowed to be in white areas. Following the police shooting of pass protesters at Sharpeville and the mass marches on Parliament in Cape Town in 1960, the ANC and PAC were banned and forced to operate underground and from exile. In exile, these organisations were more-or-less coherent, with tensions being managed, and no major splits or breakaways occurred. With the democratisation of South Africa in 1994 all the resistance movements had to adapt to a democratic and electoral mode of politics. Some members were expelled from the ANC and thereafter established new political parties. The United Democratic Movement (UDM) and 
then the Economic Freedom Fighters (EFF) are examples of such parties. In the post-1994 period, the most significant breakaway and formation of a new political party was that of Cope in 2008.

There has also been one example of party split and schism in post-apartheid South Africa, that of the DA. However, unlike the situation in Cope, as this article will show, despite a schism in the party there were no splits and splinters from the DA. Those who left the party followed one of two options: either joining an established political formation, the ANC or leaving organised politics altogether. Others remained within the DA to build its institutional and organisational establishment. Following Boucek's (2009, pp 469-78) scheme of three different types of factionalism, it is clear that within the DA the factionalism was cooperative, as opposed the competitive and degenerative forms of factionalism that appeared to be the path followed in Cope. We dwell briefly on the DA for comparative purposes, before turning attention to Cope.

Originally, the formation of DA as a political entity represented a marriage of convenience between the Democratic Party (DP), the New National Party (NNP) - successor to the apartheid-era National Party - and the lesser known Federal Alliance (FA). In 2000, the DP reached a merger agreement with the FA and the NNP, finding its precedent in the simple fact that the two main parties shared an overriding commitment to being an effective opposition party to the dominant ANC and, in the Western Cape, excluding the ANC from governing, despite it having gained the highest proportional votes in the 1999 General Election in the Western Cape. The ANC's 43\% was insufficient for the party to form a government on its own and it was unable to persuade the DP or the NNP to form a coalition government with it (Fakir 2001). The NNP then turned as a coalition partner to the DP - to whom it had lost significant electoral support in the 1999 elections. After the 1999 general election, the NNP and the DP entered into an electoral pact to keep the ANC out of the government of the province. The pact served as the platform for the start of a formal alliance, amalgamating the membership of both parties at representative institutions into a single caucus, although the parties continued to exist as separate legal entities, and later contesting the 2000 local government elections under the aegis of a single Democratic Alliance banner (Fakir 2001). The pact between the NNP and the DP to form the DA was at once a pre-electoral alliance between the NNP and the DP, leading to a phased amalgamation into a single entity at national and provincial level, and an actual government coalition in the sense that it contested the local government elections of 2000 as a political party itself and all representatives elected under its aegis were representatives of a single political party, the DA.

The relationship within in the DA between the former DP and the NNP was uneasy, 'split down old party lines resulting in a fierce political fight between the 
former DP and the former NNP' (Smith 2001). It broke down towards the end of 2001, when the NNP leader, Marthinus van Schalkwyk, took the NNP into an alliance with the ANC. To begin with the NNP was in a weak bargaining position, since it had performed poorly in the 1999 election apart from in the Western Cape. Van Schalkwyk, under pressure from NNP public representatives, and faced with the risk of the imminent collapse, calculated that an alliance with the DP seemed plausible. Given the ascendency of the DP in opposition politics at the NNP's expense after the 1999 elections, any collaboration or alliance with the DP into the DA would take place on the DP's terms. This would, however, at least provide an organisational vehicle for the survival of the NNP and its values, and potentially provide an opportunity for rebuilding, even if it at the time the NNP would be sublimated within the DA. As things transpired, this revealed itself to be a horrible miscalculation on the part of the NNP. The remaining virtue in the formation of the DA for the NNP lay in the realignment and strengthening of opposition politics.

Initially, the merger seemed to pay off, since it appears to have enthused voters. In the December 2000 local government elections the DA won 22\% of the vote compared to the ANC's 59\%. The DP had enjoyed far greater popular support at the time of the merger, and had ultimate control over the DA. The NNP component, however, had a larger signed-up membership and this introduced a fissure which was never resolved. This fissure centered on whether representation at the anticipated DA congress should be determined by electoral strength (as the DP contingent wanted) or paid-up membership, which would have been to the benefit of the NNP (Myburgh 2007).

The lack of common values, disparate and divergent ideological persuasions, the absence of a coherent political strategy, the lack of an integrated policy platform and a broader clash of cultures resulted in the emergence of one crisis after another within the first year of the formation of the DA (Fakir 2001).

Internal strife was sparked by adverse publicity caused by a street-naming scandal in which Peter Marais, DA mayor of Cape Town, who was an NNP strongman, drove a process by which Adderley and Wale Streets in the Cape Town city centre would be renamed after Nelson Mandela and FW de Klerk respectively. It was alleged that Marais had engaged in a fraudulent process of marshalling public support for the street-renaming process by submitting lists of public supporters of the move, which were alleged to have been forged, manufactured and fraudulent (Jolobe 2007, p 85).

Subsequent to these allegations, the leadership of the DA at the time, together with the Western Cape premier and Marais, agreed to establish a commission of enquiry under Section 106 of the Municipal Structures Act, headed by Judge 
Willem Heath (Jolobe 2007). Heath found Marais had 'misinformed the public' and 'stated an untruth' to Democratic Alliance leader Tony Leon about the numbers supporting his proposal. The Heath Commission also found that he had not performed the functions of his office 'in good faith, honestly and in a transparent manner' and did not act at all times in the best interest of the municipality', 'had compromised the credibility and integrity of the council, and that two unicity councillors committed fraud in the process' (Heath Special Consultants 2001, pp 71-82). These findings resulted in the suspension of the councillors, disciplinary processes for two council staff and the suspension of Marais as mayor.

From here on, however, two parallel party processes, in addition to the governmental process to deal with this matter, were instituted in an attempt to get rid of Marais altogether. For its part, the DA established a three-person dispute resolution committee to determine whether Marais had broken the new DA party rules. Simultaneously, Tony Leon bypassed the dispute resolution committee and instructed his deputy to fire Marais, while also writing directly to Marais, asking him to resign and suggesting that his failure to do so would result in a motion of no confidence in him being put to the DA's National Management Committee (NMC). At that management committee meeting Marais was dismissed. In addition to the street-naming scandal, Marais was accused of abusing his mayoral perks in a variety of ways. Marais was subsequently vindicated by the Cape High Court when he challenged the NMC decision to fire him as mayor and expel him from the DA. The judge ruled, among other things, that only the municipality could remove a mayor from office and that therefore the NMC'S decision to fire the mayor was beyond its power and was to be set aside (Jolobe 2007). Marais subsequently returned to his mayoral chambers, but he, Van Schalkwyk and others from the NNP walked out of the DA a few days later.

The street-naming saga and the political controversy that followed revealed the lack of a clear political and policy strategy, the absence of a shared ideological vision and the consequent inability to develop a common commitment to a shared base of values (Fakir 2001). The culmination, an acrimonious public spat between DA leader (Tony Leon of the DP) and deputy leader (Marthinus van Schalkwyk of the NNP) revealed the organisational, leadership and institutional vulnerabilities of the DA at the time.

This heralded within the DA a period of uncontained competitive and degenerative factionalism, which resulted in the inability to moderate the divergent approaches of party leaders and responses to issues. It also demonstrated that the policy approaches and preferences of the different leaders diverged significantly, in that, in contrast to the DP's traditional liberal posture, the NNP contingent within the DA felt ever more uncomfortable with the emergent liberal 
individualist economic strategy, which, it felt, discriminated against those who did not have the means to take advantage of an open and 'free economy', preferring models of state intervention and welfarism that was closer to the ANC's.

Having left the DA, the NNP came to a working agreement with the ANC. Following the NNP's defections, the DA lost control of both Cape Town and the Western Cape Province to the ANC. In considering whether in the early days of the formation of the DA potential cracks and schisms had an effect on the party, it would be instructive to account for the view of the party's then leader, Tony Leon, as well as to consider its electoral performance in the aftermath of the schism. Asked whether the decision to form the DA had been worth it, Leon replied ambivalently:

I think that although it caused a huge amount of grief, we have consolidated the opposition and the NP has disappeared completely. Maybe we should have tried to destroy them at the polls. That would also have had costs. There are no free choices in politics; generally one has to choose between the worse and the less worse.

Myburgh 2007

The DA was unable to shake off the damage caused by the breakup of the alliance and its aftershocks, and won only $12.4 \%$ of the vote (50 seats in Parliament) in the 2004 elections, not that much more than it had won in the 1999 elections when it had $9.6 \%$ of the vote (38 seats). It also appeared to have failed to make any inroads among black voters, which it had anticipated.

It is immaterial now, whether the disciplinary processes would have resulted in later procedural and legal expulsions, or whether the walkout of some DA members to join the ANC was pre-emptive. Organisationally, what is distinct is that no actual expulsions occurred in the fallout within the DA, even though there was a putative expulsion, which was overturned by the courts. The DA, for various reasons that will be explored briefly below, displayed fragmentation, rather than a split, proper. It later arrested the fragmentation and, unlike Cope, displayed tendencies towards opposition consolidation rather than decline.

This consolidation may continue into the future and may prospectively include an incorporation of Cope into its fold, as has already been the case with some Cope members. The DA has increased its electoral support in every successive election since 1999 and has, since 2006, institutionally incorporated the Independent Democrats (ID). It has also increased its support among the minority communities of South Africa and modestly increased its support amongst African voters (Fakir \& Holland 2011). It has further consolidated its policy trajectory and, 
unlike Cope, whose political platform and policy positions are vague, unclear and indistinct from those of the ANC, the DA has policy positions that coalesce around clearly defined themes that focus on privatisation of public enterprises through market reforms, deregulation of the labour market and a reduced role for the state in economic affairs.

Also unlike Cope, and building on the inheritance of the organisational strength of the DP, the DA has managed to build a well-defined decision-making process, an efficient party machinery, with periodic elections for leadership renewal, a constitution its members accept and whose provisions they respect, a raft of well-developed, if inappropriate policies, a branch structure and operationally effective caucuses in representative institutions. Because of this it has not yet suffered the fate of organisational split and has, instead, displayed organisational cohesion and institutionalisation.

The DA, therefore, found its genesis most properly as both a pre-election alliance and as a coalition government. What possibly saved it from complete breakdown was that it had not constituted itself legally and formally as a party at national and provincial level and was able therefore to consolidate the remnants of the NNP that remained within it into both a coherent political programme as well as a formidable organisation, leading to its institutionalisation as a party. Notwithstanding its early fragmentation and fracturing after botched internal disciplinary processes and legal proceedings, the early split in the DA can most aptly be characterised as party fragmentation rather than a party split. In contrast, Cope, after mirroring a similar set of internal contests, disciplinary processes and legal proceedings, was unable to achieve any consolidation, instead displaying tendencies towards decline after the split from the ANC.

This brief overview of breakaway parties, party fragmentation, splits and schisms in South Africa attempts to sketch a pattern and trajectory of breakaway parties and contrast it with parties in which internal contestation and schism did not give rise to breakaway parties. This has been done to provide an understanding of the prospects of breakaway parties in the context of South Africa's complex political history. In 'white' politics, breakaways to the left and right appear to have gained traction amongst their constituencies. At various times such breakaways succeeded in attracting sufficient support to emerge as significant opposition parties in the NP-dominated white parliament. In 'black' politics, breakaways to the left seem to have been more successful, as was the case of the PAC, although the party did not survive exile as well as the ANC did. This may mean that Cope, as a more-or-less centrist party, is unlikely to gain traction over time in the South African political landscape. Rather, new left parties, like the EFF, at least in rhetoric, may gain the traction to increase support and seats in Parliament so as to emerge as meaningful, as opposed to marginal, political parties. 


\section{THE SPLIT IN THE ANC AND THE FORMATION OF COPE}

The story of the split in the ANC post-Polokwane in 2007 is well documented and the facts will not be repeated here (Southall 2009; Booysen 2009; Ndletyanya 2010; Kotzé 2012). Instead, an attempt will be made to illuminate the dynamics of factionalism pre-Polokwane leading up to the split and then the formation of Cope in 2008 to contest the 2009 election. At one level, the split was driven by the differences between the two main protagonists, Thabo Mbeki and Jacob Zuma (Gilder 2012, pp 10,17). The circumstances that appear to have intensified these divisions also consolidated groupings inside the ANC, with members choosing sides. The first step in this process was the removal of Zuma as deputy president in 2005 based on the conviction of Zuma associate, Schabir Shaik, on corruption charges relating to the arms deal. This had the effect of intensifying factionalism in the ANC, with clear camps becoming further entrenched as the controversies over the National Prosecuting Authority investigation of Zuma continued. The proZuma faction perceived these actions as political and consolidated its power within the ANC, while the pro-Mbeki camp was increasingly placed on the defensive.

In the build-up to the Polokwane Conference the Mbeki camp proposed a revision of existing ANC policy, attempting to separate the office of ANC president from the presidency of the country, as elected by Parliament. The Mbeki camp thought his consolidation of a third term of office as ANC president would allow for the containment of the Zuma camp, which was destined to take over the presidency of the country in the 2009 election, when the ANC was again expected to win an overall majority in Parliament. This was an unexpected deviation from ANC practice, where the head of the ANC was also considered to be the head of state. In effect, the Mbeki camp was proposing the creation of two centres of power, hoping to capture the ANC as an organisation as a means of controlling the ANC in government.

This strategy would have enabled Mbeki to circumvent the constitutional provision limiting the person holding the office of country president to two terms. This 'new idea' was at the centre of the open factionalism demonstrated at the Polokwane Conference, where, for the first time, factions mobilised openly in the contest for positions in the ANC. At Polokwane Jacob Zuma replaced Thabo Mbeki as ANC president and, as the latter's camp was decisively defeated in the elections, Mbeki's supporters would now have limited career prospects inside the ANC.

This unsatisfactory situation, where ANC and national electoral cycles did not coincide, meant that there was an 'interregnum', during which the ANC president was not the president of the country. These two centres of power coupled to the clear change in the balance of power within the ANC led the party's National 
Executive Council to recall Mbeki as president of South Africa in September 2008, replacing him with Kgalema Mothlanthe. When the ANC won the 2009 election Jacob Zuma became the country's president.

Mbeki's decision to resign as state president may have served as a reconciliatory gesture to re-unite the ANC's factions. However, shortly after Mbeki's recall, the divisions in the ANC manifested themselves as a clear split and breakaway when Mbeki supporter and soon-to-be Cope leader, Mosiuoa Lekota (a former ANC Cabinet minister and former chairperson of the ANC), announced a divorce from the ANC. Between November and December 2008 those leaving the ANC mobilised support and held a convention and an electoral process that resulted in the formal establishment of a new political party, the Congress of the People.

One of the puzzles in the emergence of Cope is the fact that Thabo Mbeki did not formally join the nascent party, or show any overt support for it. Many analysts appear to have believed that he welcomed the formation of Cope, especially after his mother, a long- standing ANC and South African Communist Party member, joined the new party. This belief remains speculative, since there is no definitive evidence that Mbeki was actually involved in the formation of Cope or supported it once it was established. There have been attempts, tacit in our view, to 'link Mbeki to providing policy input and direction, to Cope' (Jika 2011), and vehement denials issued by Mbeki's spokesperson about Mbeki being a member of Cope, and re-iterating that Mbeki remained an ANC member.

There are at least three possible reasons why Mbeki avoided aligning himself with Cope:

- His defeat at Polokwane in the ANC presidential contest might have been an embarrassment and therefore a significant disincentive for his continued involvement in party political life;

- As the driver of the New Programme for Africa's Development (Nepad), Mbeki was instrumental in entrenching a two-term limit for heads of state and could not be seen to be trying to get back into politics via a new political vehicle; or

- Mbeki possibly could not make the emotional break with the ANC which had shaped him for almost his entire life.

Perhaps the fact that Mbeki welcomed the formation of Cope lay in his support for the principle of multiparty democracy and the emergence of a new party to participate in South Africa's young democracy.

The origin of Cope as a fragment of the ANC is a significant factor in determining its performance as a political party (Kotzé 2011). Ndletyana (2010) 
summarised Cope's posture as focusing on 'morality, constitutionalism and meritocracy'. Cope set itself up as a non-racial social democratic party, distinct from the ANC and established to address the impasse over socio-economic development and quality government services. In reality, however, it was unable to distinguish itself from the ANC and was reminiscent of the ANC's position as an all-embracing broad church (Booysen 2009, p 179). Its programme was typical of those of breakaway parties in that it held onto symbols, events and policies related to its parent body, while claiming to be their true guarantor. While now opposing the ANC, Cope also claimed to be a bastion of values and policies the ANC had lost sight of, or deviated from. Thus it did not present anything new, or an alternative to the ANC, but presented itself as the custodian of true ANC tradition and values.

The trajectory of the breakaway from the ANC and the formation of Cope illustrates the theoretical points discussed above. First, Mbeki's suggestion that the positions of ANC president and state president be separated marks the way party rules and conventions are interpreted and modified in the heat of factional battles. Moreover, as Sartori (2005) notes, the strategic use of rules reveals the deep-seated, subterranean conflicts within parties.

Having lost the election for ANC president, Mbeki was left in a vulnerable position as state president, leading to his recall from office and the reinforcement by the Zuma-dominated ANC of the past practice of ensuring that the two positions were held by the same person.

Similarly, the events leading up to the split in the ANC and the formation of Cope also illustrate the process model of breakaways developed by Dyck \& Starke (1999). In terms of 'Idea Development', Mbeki's removal of Zuma as deputy president in 2005 indicated an intention to prevent Zuma from succeeding him after the 2009 election. This catalysed factional identity and choosing of sides by ANC members, which kick-started the following stages of change, resistance, conflict and, finally, exit.

The propagation by the Mbeki camp of a new approach to the role of ANC president by separating it from the office of state president sparked intense resistance from the now-dominant Zuma camp, resistance that intensified and climaxed at the Polokwane Conference. With leadership at the centre of the conflict, there was little prospect of a mediated reconciliation of the factions. This left the defeated faction with few options, resulting in its exit from the ANC. This process analysis of the split attempts to illuminate, rather than describe, the formation of Cope, by indicating that it follows a pattern similar to other examples set out in organisational theory approaches to splits and breakaways. Nonetheless, having broken from the ANC, Cope had to fight elections to see whether citizens 
perceived it as separate from the ANC or as the protector of the values and policies that the ANC once stood for, but from which it had now deviated.

In 2009 Cope used the slogan, 'A new agenda for Hope and Change for all', with a manifesto that included

defending the constitution and rule of law, eradication of poverty, economic growth, job creation, protection of the environment, quality globally competitive education, good health care, reducing crime, empowering women, youth development, strengthening of families and to unite to make South Africa better place.

Kotzé 2011, p 175

Cope's 2011 local government manifesto set out to address a series of issues and challenges in society that had been ignored. According to Kotzé (2011, p 79), Cope's election manifesto aimed to address the alleged impasse in socio-economic development and the provision of quality government services. There was little there to distinguish Cope from any other political party, and the manifesto reads, in various ways, very much like that of the ANC. Regardless, Kotzé 2011, Booysen 2009 and Ndletyana 2010 position Cope as an entrepreneurial party. However, caution must be exercised in interpreting Cope's establishment in hindsight, without due regard for its origins in the factional ideological, policy and leadership contestation within the ANC. Its formation had more to do with factionalism and leadership contests within the ANC than with those who established it being political entrepreneurs setting out to identify and address latent, new and unnoticed issues in society.

The new party cannot escape its association with the parent party, and the nature of the ensuing political and identity contests, as well as leadership struggles and policy disputes, shape the nature and character of the new entity. While it emerges from a parent party the new entity tries to differentiate itself from that party in order to attract votes. This type of political entrepreneurship usually entails claiming to represent the true values and vision of what the new party now refers to as the misguided original parent party.

\section{COPE'S LEGAL WRANGLES AND THE SEEDS OF DECLINE.}

After splitting from the ANC, Cope, held its inaugural congress in Bloemfontein on 16 December 2008. Here Mosiuoa Lekota was appointed president and Mbhazima Shilowa, a former ANC provincial premier, was appointed deputy president. At the congress, Cope adopted its inaugural constitution. Because its leaders 
were appointed rather than elected, clause 2.9 of the party's 2008 constitution provided that

The inaugural Congress of the Congress of the People shall agree by Resolution that the First National Congress of the Party shall be held within a maximum of 2 years, following the establishment of Party structures at branch, regional and provincial level as well as the Congress of the People Chapters in accordance with the provisions of this Constitution.

It is in this particular clause that the seeds of leadership contestation and subsequent party fracture and fragmentation lay, precipitating an almost fouryear battle for leadership of the party.

In line with its inaugural constitution Cope attempted to hold an elective conference from 27 to 30 May 2010. The conference was planned amid emerging tensions in the party over leadership bids by Lekota and Shilowa, with accusations of fraud and corruption levelled by Lekota against Shilowa. In a compromise bid to avoid court action to call off the planned conference, the Congress National Committee ( $\mathrm{CNC}$ ) decided a week before the conference to focus the party's attention on policy matters rather than to make the conference an elective one. At the conference, however, delegates passed a resolution that it be held as an elective conference, sparking a walkout from the Lekota faction.

At a press briefing on the day of the conference Lekota again levelled accusations of 'fraud, corruption, and patronage committed with public funds at both the national level and various provinces, against his rival Shilowa' (News24 2010).

Despite the walkout and the fact that Lekota and his supporters were vehement that the conference not proceed, the Shilowa faction continued to hold a conference, going as far as passing a vote of no confidence in Lekota. In effect, this purported to elect Shilowa, as interim president, giving rise to competing claims to be Cope's legitimate president. Sparking allegations that this was a malicious move by Shilowa to eject Lekota from Cope, Lekota, in response, approached the courts to prevent what he alleged to be the hijacking of Cope. The court ruled in favour of Lekota, suggesting that 'Shilowa's election was in contravention of the spirit of the resolution taken by Cope's $\mathrm{CNC}^{\prime}$. In addition, the court granted Lekota the relief he sought, interdicting Cope from conducting elections for four months (News24 2010). Shilowa appealed the judgement, making it clear that the party's leadership of Cope was likely to be determined by the courts rather than by its members. 
As it turned out, Shilowa lost the appeal and the court reinstated Lekota as the party's leader, stating that Shilowa's nomination to the position was unconstitutional. In the intervening period a further congress was held, on 15 and 16 December 2010, at Heartfelt in Pretoria, at which it is claimed that Shilowa was elected president of Cope. But by February 2011 Shilowa had been expelled from the party and as a Cope member of Parliament after a party disciplinary hearing had found him guilty of 'wrongfully authorising the transfer of R5-million from the parliamentary allowance accounts to Cope party accounts and of submitting the party's financial statements to Parliament knowing that they contained material misrepresentations'. It also found him guilty of authorising a payment of more than R2-million 'for purposes that were not legitimate or permissible' (Cope statement, February 2011).

This gave rise to a further court case, which traversed the entire gamut of issues listed here and resulted in a final set of judgements which confirmed all Lekota's contentions against Shilowa. In a final judgement, Acting Judge Watt_ Pringle (Congress of the People and Mosiuoa Lekota vs Mbhazima Shilowa and others) found, among other things, that:

- The interim leadership's term of office did not end on 16 December 2010;

- No legitimate new CNC was elected in December 2010 at Heartfelt;

- There is no finding to the effect that Lekota was relieved of his duties as office bearer or representative of Cope; and

- There is no finding to the effect that Lekota started a parallel leadership structure, declared himself President, and refuses to recognise Shilowa as President of Cope.

These findings confirmed Lekota's leadership of Cope, nullified Shilowa's claim to leadership and served to legitimate Shilowa's expulsion as both a member of Cope and as a member of Parliament.

Though there are similarities between what happened in the DA in its early formation, as described above, the DA was, perhaps, saved by the fact that it was a pre-election alliance at national and provincial level and a coalition government at the local level. The fragmentation of the DA was arrested by the voluntary nature of one of the partners leaving, thereby avoiding prolonged leadership contests and possible court action. This was aided by the fact that DA members had two exit options, while Cope appeared to be a vehicle for disgruntled former ANC members who had lost their positions in the parent party. This contributed to the decline of Cope, rather than the fragmentation that was germane in the DA. 


\section{COPE'S ELECTION PERFORMANCE BETWEEN 2009 AND 2014}

Table 1

Cope's performance in the 2009 national election

\begin{tabular}{|l|r|c|c|c|}
\hline & $\begin{array}{c}\text { Total number } \\
\text { of votes }\end{array}$ & $\begin{array}{c}\text { Percentage } \\
\text { share of votes }\end{array}$ & $\begin{array}{c}\text { Total number } \\
\text { of seats / total } \\
\text { seats }\end{array}$ & $\begin{array}{c}\text { Percentage of } \\
\text { seats }\end{array}$ \\
\hline National & $1,311,027$ & 7.4 & $30 / 400$ & $7.5 \%$ \\
\hline Eastern Cape & 308,439 & 13.67 & $9 / 63$ & $14.2 \%$ \\
\hline Free State & 120,018 & 11.61 & $4 / 30$ & $13.3 \%$ \\
\hline Gauteng & 323,327 & 7.78 & $6 / 73$ & $8.2 \%$ \\
\hline KwaZulu-Natal & 44,890 & 1.29 & $1 / 80$ & $1.25 \%$ \\
\hline Limpopo & 112,325 & 7.53 & $4 / 49$ & $8.1 \%$ \\
\hline Mpumalanga & 37,789 & 2.91 & $1 / 30$ & $3.33 \%$ \\
\hline North West & 89,573 & 8.33 & $3 / 33$ & $9 \%$ \\
\hline Northern Cape & 67,416 & 16.67 & $5 / 30$ & $16.6 \%$ \\
\hline Western Cape & 152,356 & 7.74 & $3 / 42$ & $7.1 \%$ \\
\hline
\end{tabular}

Source: Compiled from data from the Electoral Commission of South Africa

In the general election of 2009 Cope won $7.4 \%$ of the vote, a remarkable achievement for a new party. In the local government election of 2011, however, it won a mere $2.22 \%$, although it won $11.7 \%$ of the vote in the Northern Cape. However, the turnout for the general election was $77.3 \%$ of registered voters, while, in 2011, for the local government elections, it was 57.6\%, so Cope's performance could be said to mirror proportionately its performance in the 2009 elections.

In fact, the party already appeared to be shedding support because of its internal schisms and in Gauteng the drop in support between 2009 and 2011was cataclysmic. It is possible that many potential Cope voters simply did not vote in 2011 and that there was a real decline after the prolonged and acrimonious court cases that began in 2010. However, the party's most dramatic decline took place between the 2011 local government elections and the 2014 national elections.

Moreover, given that political effectiveness, representation and institutional presence matters more for political effect than percentage support, especially in mixed member proportional voting systems such as that used in South Africa's local elections, the 2011 local government elections results confirm two long-held postulates. First that Cope's support is spread across the country. Governance effectiveness is measured by concentration of representation and Table 2 shows 


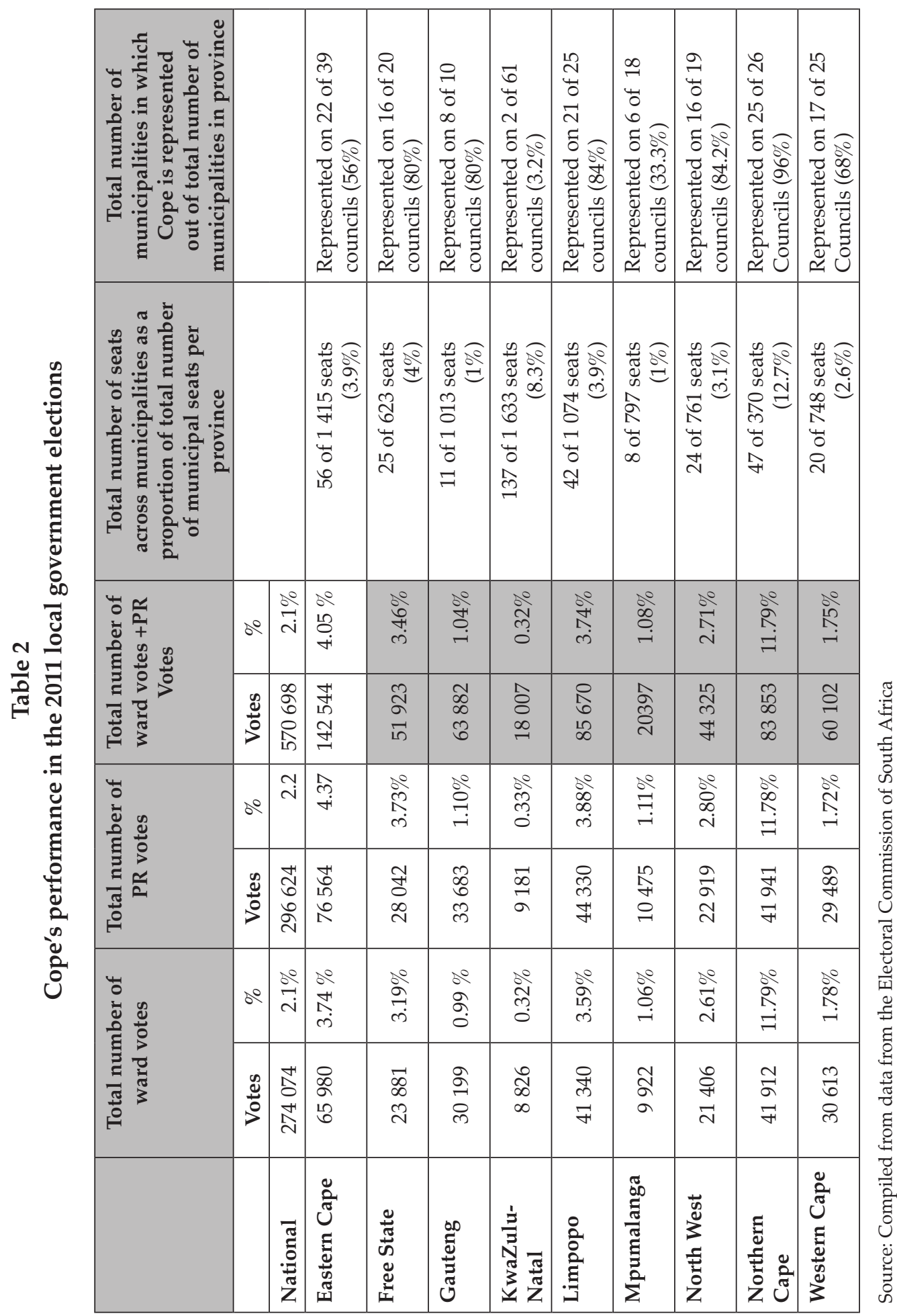


how thinly represented Cope is in local councils. Curiously, it also demonstrates that only in two provinces (KwaZulu-Natal and Mpumalanga) does it not have representation in more than $50 \%$ of councils. In the majority of instances it is represented on $80 \%$ of councils.

In contrast, Table 3 details the complete decline of Cope and, contrasted with the findings of Table 2, demonstrates not only a percentage aggregate decline but a decline in representation and support across the country.

Table 3

\section{Cope's performance in 2014 national elections}

\begin{tabular}{|l|c|c|c|c|}
\hline & $\begin{array}{c}\text { Total number } \\
\text { of votes }\end{array}$ & $\begin{array}{c}\% \text { share of } \\
\text { votes }\end{array}$ & $\begin{array}{c}\text { Total number } \\
\text { of seats / total } \\
\text { seats (seats } \\
\text { lost) }\end{array}$ & $\begin{array}{r}\% \text { of } \\
\text { seats }\end{array}$ \\
\hline National & 123235 & 0.67 & $3 / 400$ (lost 27) & 0.75 \\
\hline Eastern Cape & 26129 & 1.20 & $1 / 63$ (lost 8$)$ & 1.5 \\
\hline Free State & 16516 & 1.63 & $0 / 30$ (lost 4) & 0 \\
\hline Gauteng & 21652 & 0.49 & $0 / 73$ (lost 6) & 0 \\
\hline KwaZulu-Natal & 5968 & 0.16 & $0 / 80$ (lost 1$)$ & 0 \\
\hline Limpopo & 2573 & 0.86 & $1 / 49$ (lost 3) & 2 \\
\hline Mpumalanga & 4288 & 0.32 & $0 / 30$ (lost 1$)$ & 0 \\
\hline North West & 8692 & 0.80 & $0 / 33$ (lost 3) & 0 \\
\hline Northern Cape & 15218 & 3.60 & $1 / 30$ (lost 4) & 3.3 \\
\hline Western Cape & 12520 & 0.59 & $0 / 42$ (lost 3) & 0 \\
\hline
\end{tabular}

Source: Compiled from data from the Electoral Commission of South Africa

In 2014 Cope managed to retain only three provincial seats in total, one each in the Eastern Cape, Limpopo and the Northern Cape, a fraction of the 36 seats it had won across the nine provinces in 2009. In the National Assembly it retained only three of the 30 seats it had held since 2009.

\section{CONCLUSION}

As demonstrated by Southall (2009), Booysen (2009), Ndletyana (2010) and Kotzé (2012), Cope's decline can be attributed to several different factors, including a vague and indistinct ideological persuasion, the absence of a coherent political strategy, the lack of an integrated policy platform, and a vicious leadership contest 
without sufficient internal institutional development and conflict mitigation structures and processes as well as a lack of access to resources.

Primarily, however, we argue that its decline can be traced to its origins within the factional contestation in its parent party, the ANC. Unlike the DA, Cope was unable to extricate the remaining leadership and membership from a vague policy approach and squabbling over positions, nor to agree on processes and procedures. It was also unable to isolate its members from its vague and indistinct ideological and policy cleavages, nor insulate its members and voters from a bitter leadership battle.

As the judge observed in handing down his findings in one of the Cope court cases, 'I can only hope that this proved cathartic to the large, attentive and good natured gallery, because it certainly lengthened the trial' (AJ Watt-Pringle, Cope and Mosiuoa Lekota vs Mbhazima Shilowa and others, para 93.6, p 43).

Unlike antagonists within the DA, who had two exit options, antagonists in Cope had a proliferation of options, including returning to the parent party, the ANC, which appears to have been the most significant contributor to its decline. The multiple court cases as well as identity and leadership fracture and expulsions contributed to the overarching importation of political conflict from the parent party.

\section{- REFERENCES}

Asal, V, M Brown \& A Dalton. 2012. ‘Why Split? Organizational Splits among Ethnopolitical Organizations in the Middle East'. Journal of Conflict Resolution 56(1).

Barnea, S \& G Rahat. 2010. 'Out with the old, in with the "new": What constitutes a new party?' Party Politics 17(3).

Benton, A. 2007. 'The Strategic Struggle for Patronage, Political Career, State Largesse, And Factionalism In Latin American Parties'. Journal of Theoretical Politics 19(1).

Booysen, S. 2009. 'Congress of the People: Between Foothold of Hope and Slippery Slope'. In R Southall \& J Daniel (eds). Zunami! The 2009 South African Election. Johannesburg: Jacana.

Boucek, F. 2009. ‘Rethinking Factionalism: Typologies, Intra-Party Dynamics and Three Faces of Factionalism'. Party Politics 15(4).

Carty, R K. 2004. 'Parties as Franchise Systems: The Stratarchical Organizational Imperative'. Party Politics 10(1).

Davenport, T. 1984. South Africa: A Modern History. Johannesburg: Macmillan.

Dexter, P. 2011. 'Shilowa expelled from Cope'. Cope Press Statement, 8 February.

Dyck, B \& F Starke. 1999. 'The Formation of Breakaway Organizations: Observations and a Process Model'. Administrative Science Quarterly 44. 
Fakir, E. 2001. 'Divorce for the DA?'. E-Politics.SA 34, 19 September. Institute for Democracy in South Africa.

Fakir, E \& W Holland. 2011. 'Changing voting patterns?' Journal of Public Administration 46.

Gilder, B. 2012. Songs and Secrets. Johannesburg: Jacana.

Heath Special Consultants. 2001. Investigation in terms of Section 106 of the Provincial Government. Municipal Systems Act, 32 of 2000. Proposed Renaming of Adderley and Wale Streets.

Jolobe, Z. 2007. 'Things fall apart, can the centre hold?: The state of coalition politics in the Cape Metropolitan Council'. In S Buhlungu, J Daniel, R Southall \& J Lutchman (eds). Cape Town: HSRC Press.

Kotzé, D. 2012. 'Cope - Grandiose entrance and micro-status'. In S Booysen (ed). Local elections in South Africa: Parties, people, politics. Stellenbosch: Sun Media. Lodge, T. 1983. Black Politics in South Africa since 1945. Johannesburg: Ravan Press. Machiavelli, N. 1985. The Prince. Harmondsworth: Penguin.

Myburgh, J. 2007. 'Reflections on the DA of Tony Leon', Moneyweb, 2 and 3 May. Available at:

www.politicsweb.co.za/ documents / reflections-on-the-da-of-tony-leon

Ndletyana, M. 2010. 'Congress of the People: A Promise Betrayed'. Journal of African Elections 9(2).

News24. "Mbeki behind Cope policy", Thanduxolo Jika. Available at: www.news24. com/SouthAfrica/Politics/Mbeki-behind-Cope-policy-WikiLeaks-20110112

News24. 'Cope battle escalates'. Available at: www.news24.com/SouthAfrica/ Politics / Cope-battle-escalates-20100529

News24. 'Cope to respect Interdict'. Avilable at: www.news24.com/SouthAfrica/ Politics / Cope-to-respect-interdict-20100529.

Sartori, G. 2005. Parties and Party Systems. Colchester: ECPR Press. Available at: www.consensocivico.com.ar/ uploads/5495c37c979a2-Sartori-Parties\%20 and $\% 20$ Party $\% 20$ Systems $\% 28 \mathrm{CC} \% 29$.pdf).

Southall, R. 2009. 'The Congress of the People: Challenges for South African Democracy'. Representation 45(2).

Smith, A. 2001. 'ANC "in talks with Nats on DA's hitlist"'. Cape Times, April 6. Available at: www.iol.co.za/news/politics/anc-in-talks-with-nats-on-das-hitlist-1.63740?ot=inmsa.ArticlePrintPageLayout.ot

Verge, T \& R Gomez. 2012. 'Factionalism In Multi-Level Contexts: When Party Organization Becomes a Device'. Party Politics 18(5).

Watt-Pringle (AJ). 2011. Judgement. Congress of the People and Mosiuoa Lekota vs Mbhazima Shilowa and Others. Case number 6779/2011, 18 October.

Zons, G. 2013. 'The Influence Of Programmatic Diversity On The Formation Of New Political Partie's. Party Politics (online first) doi: 10.1177/1354068813509515. 